\title{
Konfliktipelglik ja kõneosav vaikimine: kõrts kui kommunikatsiooniruum Saksa keisririigis
}

\author{
Armin Owzar \\ Pariisi 3. Ülikooli (Sorbonne Nouvelle) ajalooprofessor \\ armin.owzar@sorbonne-nouvelle.fr
}

\begin{abstract}
Teesid: Saksa keisririik oli keiser Wilhelm II valitsuse all räsitud arvukatest sotsiaalsetest, poliitilistest, religioossetest ja etnilistest konfliktidest. Kuidas inimesed nende konfliktidega argielus toime tulid? Kirjeldades urbanistliku keskkonna (eelkõige Hamburgi) erinevaid segmente ja nendevahelise suhtlemise vorme kõrtsides, püüab käesolev artikkel sellele küsimusele vastata. Kahekümne kahe aasta jooksul kõrtsides peetud vestluste põhjal koostatud umbes 20000 kaitsepolitsei valveraporti kvalitatiivne ja kvantitatiivne analüüs näitab, et erinevate ühiskonnasegmentide vahel ei toimunud peaaegu mingit kommunikatsiooni. Kui suhtlusolukorrad ka tekkisid, ei räägitud tavaliselt poliitikast ega identiteeti, veendumusi või uskumusi puudutavatest teemadest. Artiklis osutatakse sellise käitumise põhjustele, mis on nii antropoloogilised (näiteks isolatsioonihirm) kui ka absolutistlikust autoritaarriigist tulenevad, ning vaikimise rollile ühiskondlike konfliktidega toimetuleku moodusena.
\end{abstract}

Märksõnad: kommunikatsioon, kõrtsid, Saksa keisririik, sotsiaalajalugu, vaikimine

\section{Sissejuhatus}

Kõrts olevat "vaese rahva salong" (Levenstein 1912: 244) "teatud sorti rahvaülikool" (Schult 1954: 42f), "proletaarlase poliitilise vabaduse kants" (Kautsky 1890/91: 106) - juba Saksa keisririigi kaasaegsete hulgas polnud vähimatki kahtlust kõrtside keskse rolli suhtes töölisklassile. Kui välja arvata mõned vähesed, nagu Saksa Töötajate-Karsklaste Liit, ${ }^{1}$ ülistasid sotsiaaldemokraadid kõrtsi kui asendamatut kohta proletariaadi poliitiliseks emantsipatsiooniks, lähtudes muuhulgas oma kogemustest sotsialistide vastaste seaduste perioodil: oli ju kõrts end tõestanud peaaegu ideaalse kaitsekorterina tagakiusatud töölisseltsidele. Ajaloouurimises on see eelkõige Karl Kautsky poolt populariseeritud tõlgendus valdavalt üle võetud ja täiendust saanud (vt nt Roberts 1980). Kõrtsi osatähtsust “argipaigana" (vt Haupt 1994) ei saa tõepoolest alahinnata. Sellest 
annab tunnistust juba ainuüksi nende üleriigilise võrgustiku olemasolu saksa keisririigis, ${ }^{2}$ eriti aga nende funktsioonide mitmekesisus. Kõrts oli "poolavalik ühiskondlik vabaruum", mille piiridest politseil oli vaid piiratud määral voli üle astuda (Machtan 1983: 62). Töötute puhul toimis see ajaveetmise kohana, tööotsijate puhul töövahendusplatvormina, töötajate puhul tööpauside- ja vaba aja täitmise paigana. ${ }^{3}$ Töölised, aga ka keskklassi liikmed kogunesid siia õhtuti, vahel ka hommikuti ja lõunati ning sugugi mitte ainult toidu ja joogi pärast, vaid ka selleks, et vestelda, privaatsete ja avalike küsimuste üle arutleda. Sest kõrts oli alati ka üks suhtluskeskusi, kui mitte koguni kesksena eelistatud suhtluskeskus (vt ka Mania 1997). Põhimõtteliselt oli sellele ligipääs olemas kõikvõimalike koguduste, poliitiliste leeride, peaaegu kõigi põlvkondade ja mõlema sugupoole liikmetel: nii valgekraedel kui töölistel, sotsiaaldemokraatidel kui liberaalidel, juudivastastel, juutidel ja kristlastel, meestel ja naistel, kohalikel ja sisserännanutel.

Võttes arvesse mitmekülgseid, süvitsi tungivaid ja trükimeedia kaudu peaaegu kõigi riigi kodanike teadvusesse jõudnud konflikte, mille osapoolteks need grupid toonases keisririigis olid, tekib küsimus, kuidas nad nendega kõrtsis ümber käisid, millise väljundi leidsid argisuhtluses poliitilised vastuolud, sotsiaalsed võimuvõitlused hüvede pärast ja kultuurilised identiteedikonfliktid. Sellega haakub ka küsimus, kuidas need grupid omavahel lävisid. Lõppude lõpuks koosneb sotsiaalne käitumine suuresti kommunikatsioonist (vrd Watzlawick \& Beavin \& Jackson 1990: 51). Sellest vaatenurgast lähtuvalt on loogiline küsida mitte ainult suhtluse sisu, vaid ka suhtlusvormide kohta - ehk siis mitte ainult selle kohta, mille üle, vaid ka kuidas üksteisega vaieldi. Ja kuna konfliktide avaldumisvormide puhul on üldjuhul tegemist kollektiivsete käitumismustritega, tõusetub ka küsimus kommunikatiivse käitumise põhjuste ja tagajärgede kohta: millistest ühiskondlikest konstellatsioonidest see tõukus ja milline oli selle mõju ühiskondlikule arengule sõdadevahelisel perioodil. Sealjuures on eelduspärane, et kommunikatiivses käitumises esines vastavalt sotsiaalsele staatusele, seotusele ühiskondliku miljööga, soolisele kuuluvusele ja organiseerituse astmele spetsiifilisi erinevusi. ${ }^{4}$ Kuidas saab seda oletust aga empiiriliselt tõestada?

Järgnevas otsitakse inimestevahelise suhtluskäitumise komplekssust analüüsides vastust kolmele küsimusele. Esiteks, kas erinevate poliitiliste leeride ja keskkondade, erinevate ühiskonnakihtide, usukogukondade, rahvuste ja sugude esindajad üldse vestlesid omavahel? Teiseks, juhul, kui nad vestlesid, siis millest? Kas puudutati ka teemasid, mis lasksid päevavalgele tulla eriarvamustel ja vestlejate erinevatel identiteetidel? Ja kolmandaks, milline oli sellistel juhtudel vestluste kulg? Kuidas tuldi toime arvamuste lahknemisega? 
Eelkõige just 1890. aastatel maad võtnud fundamentaalne poliitiline kurss Saksa ühiskonnas õigustab nendele küsimustele vastamisel keskendumist 20. sajandi vahetuse eelsele ja järgsele kümnendile (vrd Ullmann 1999: 25). Seda enam, et sotsiaaldemokraatliku ja katoliku mõjusfääri kujunemisega olid saanud poliitilisest meelsusest ja usulisest kuuluvusest sotsiaalse korra eristusmarkerid (vt Nipperdey 1990: 428-468; Ritter \& Tenfelde 1992). Seoses juudivastasuse esiletõusuga ja diskussioonidega nn naisküsimuse üle olid tõusnud fookusesse veel kaks paljude vestlustes osalejate identiteeti tihedalt puudutavat teemat (vt Berding 1988: 86-164; Planert 1998).

Kuna suurtes linnades arenesid sotsiaalsed suhted üldisest komplitseeritumalt, avaldusid siin ka konfliktid eriti jõuliselt. Kui järgnevas analüüsis võetakse luubi alla hansalinn Hamburg, siis mitte ainult sellepärast, et see kujutas endast eriti kõrge konfliktitasemega multikultuurilist mikrokosmost, ${ }^{5}$ vaid ka seda linna puudutava peaaegu ideaalse allikmaterjali olemasolu tõttu. Nimelt on meil umbes 20000 algselt Richard J. Evansi korrastatud ja Hamburgi kaitsepolitseilt pärit valveraportite näol tegemist pärimusega, mis annab paremini kui ükski teine materjalikogu ülevaate kommunikatiivsest käitumisest Hamburgi kõrtsides. ${ }^{6}$ Inkognito kirjapanekuid teinud politseinikud, kes seal aastail 1892-1910 peaaegu igapäevaselt korjel käisid, et poliitilise meelsuse kohta raporteid koostada, ei pannud kirja mitte ainult arvukate vestluste sisu, vaid kirjeldasid korduvalt ka vestluse kulgu ja viisi, kuidas selles osalejad üksteisega rääkisid. Lisaks leidub märkmeid osaliste sotsiaalse, poliitilise, etnilise ja soolise kuuluvuse kohta ning selle kohta, keda kõrtsides kohata võis, kes kellega rääkis ja kes kellega ei rääkinud.

\section{Suhtluskogukonnad}

Ka mees, kes rahvast täis ootesaalis, nina maas, põrandat põrnitseb või silmad suleb, osaleb kommunikatsioonis: annab ta ju sellega teistele kohalviibijatele teada, et ta ei soovi rääkida ega ka kõnetatud saada. "Pole võimalik kommunikatsioonis mitte osaleda," on selliste olukordade põhjal järeldanud Paul Watzlawick. Kuna vaikimine kujutab endast teadlikku alternatiivi verbaalsele või žestidel ja mimeetikal põhinevale mitteverbaalsele kommunikatsioonile, on ometi tegemist inimestevahelise kommunikatsiooniga (Watzawick \& Beavin \& Jackson 1990: 53). Selle arusaama kohaselt tuleks ka ühiskonna suurrühmade liikmete segregatsioonist tingitud käitumist vaadelda kommunikatsiooniaktina, kuna see tuleneb teadlikust otsusest.

Loomulikult on ka ruumilisi, materiaalseid ja ajalisi tegureid, mis vähemalt teatud määral vaba aja raames toimuvat segregatsioonikäitumist tingivad: ini- 
mese käsutuses olev rahaliste vahendite hulk, erinev ajakasutuse korraldus, ${ }^{7}$ muuhulgas ka elutingimused. Need on tegurid, mis avaldasid mõju just sellistes sotsiaalses mõttes suhteliselt homogeensetes Hamburgi linnakvartalites, nagu suurilmalik Harvestehude, külalik Horn ning Neustadti lõunaosa vaesteagul (üldisemalt vt Wischermann 1983). Teisalt oli muidugi ka mitmeid sotsiaalses, usulises ja etnilises mõttes segunenud linnaosasid, nagu Eimsbüttel või Eppendorf, milles poolakad ja sakslased, protestandid ja juudid, töölised ja õpetajad, sotsiaaldemokraadid ja juudivastased külg külje kõrval elasid. ${ }^{8}$ Just nende linnaosade kõrtsid on järgnevas käsitluses luubi all, kuna siin kõikjal täheldatav segregatsioon on muude määratlevate tegurite oluliselt väiksema ulatuse tõttu üheselt seostatav teadliku tegutsemisega. Järgnevas eristatakse kolme kõrtsitüüpi: avatud, poolavatud ja kinnine asutusetü̈̈p. Nii nagu avatud asutusetüübis, käib ka poolavatus koos heterogeenne kooslus, kuid teeb seda erinevatel aegadel või üksteisest hierarhiapõhiselt eraldatud ruumiosades (erinevates tubades või erinevate laudade juures). Kinnises kõrtsitüübis võib aga kohata peaaegu eranditult ainult ühe ja sama rühma liikmeid. Teadmatule külastajale annab siin hulk mitteverbaalseid ja verbaalseid märke vihjeid selle kohta, millised külalised on teretulnud ja millised mittesoovitud.

Valveraportite kvantitatiivne analüüs näitab, et kinnine asutusetüüp oli kõrtsimaastikul ülekaalus. Külastajad organiseerusid eelkõige vastavalt sotsiaalsetele eraldusjoontele. Ainult 11,1 protsendis vaatlusalustest kõrtsidest kohtasid ametnikud sotsiaalses mõttes segunenud klientuuri. 2,2 protsendil juhtudest oli tegemist poolkinnise asutusetüübiga, enamasti olid need kõrtsid, mida hommikul ja lõunal külastasid töölised ning õhtuti keskklassi kuuluvad kliendid. Absoluutse enamuse (86,7 protsenti) moodustas kinnine asutusetüüp. Seda tüüpi kõrtse külastas enamasti töölisklass (88 protsenti); kõrgematesse ühiskonnakihtidesse kuuluvaid külalisi oli ainult 12 protsenti. ${ }^{9}$ Kõrgklassi liikmeid nende hulgas ei olnud, kuna hansaeliidil ei olnud kombeks - kui ärilõunad ja -õhtusöögid välja arvata - peaaegu üldse väljas käia. Hoiti omaette - kas viibiti pere rüpes või läviti kitsa sõpraderingiga. ${ }^{10}$

Enamasti oli võimalik juba välisel vaatlusel aru saada, milline seltskond mingi kõrtsi klientuuri moodustas. Arvukate mitmekorruseliste majade keldrites asuvate lokaalide puhul oli eranditult tegemist tööliskõrtsidega. Juba ainuüksi allapoole viivale sissekäigutrepile astumine pidi keskklassist külalisele tekitama tunde sotsiaalses mõttes madalamale tasemele liikumisest. Järgmisena kujutasid välisuksele kinnitatud seltsisildid märguannet selle kohta, milline klientuur antud kohas koos käib. Hiljemalt kõrtsi sisenemisel teavitas sellist külastajat pilguheit kasinale mööblile, et ta on sattunud valesse kohta. Ning teisalt peletas juba keskklassi klientuurile suunatud lokaali soliidne välisilme lihtsa töölise eemale. Ka sellistes asutustes pakutaval joogikaardil oli välistav 
funktsioon: kohtades, kus pakuti veini ja likööri, eeldati ontlikke külastajaid; lihtinimene pidi rahul olema kange alkoholi ja õllega. Külastaja, kes kõik eelnimetatud märgid kahe silma vahele jättis ja ka teise ühiskonnakihti kuuluva klientuuri riietust ja pilke vihjena võtta ei osanud, kamandas kõrtsmik üpris tihti rohmakal viisil ise kõrtsist välja.

Ent mitte ainult ühiskonnaklasside ja -kihtide vahel, vaid ka alamkihi enda hulgas jooksid peaaegu ületamatud piirid. James S. Robertsi väide, mille järgi kõrts olevat võimaldanud elukutse- ja valdkonnaülest suhtlust ning aidanud seega kaasa linlaste erinevate rühmade vahelisele läbikäimisele ja üksteisemõistmisele (vt Roberts 1980: 126j), on võimalik valveraportite statistilise analüüsi põhjal selgelt ümber lükata. Uurides valikuliselt 184 kõrtsiraportit, mille puhul olid olemas andmed külastajate elukutse kohta, ilmnes, et ainult 35 protsendil juhtudest toimus kokkupuude erinevate töövaldkondadega tegelevate madalama ühiskonnaklassi esindajate vahel. Rohkem kui pooltel sellistel juhtudel oli kontaktide üheks osapooleks voorimees või postiljon, kes oma tööst tulenevalt olid lausa sunnitud oma lühikest puhkepausi lähimas (töölis-)lokaalis veetma. Sadamatöölised ja sellid, tänavapuhastajad ja töötud, vabriku- ja ehitustöölised, maalrid ja lihunikud - kõigil nendel rühmadel olid oma püsilokaalid. Kui välja jätta voorimehed ja postiljonid, siis leidsid kõigist vaadeldud suhtlusolukordadest ainult 12,9 protsendil juhul aset elukutseülest laadi suhtluskontaktid. ${ }^{11}$

Sarnase ulatusega segregatsiooniprotsess oli vaadeldav kõrtside klientuuri poliitilise kuuluvuse osas. Sotsialistide vastaste seaduste aegadest peale oli kõrtsides suurenenud eelkõige sotsiaaldemokraatia haare ja need asutused olid muutunud vastavate salajaste kogunemiste keskseks paigaks. Ka hiljem säilis kõrtsi toimimine poliitilise kommunikatsiooni keskusena. Erilist rolli paljude kõrtside muutumisel eranditult sotsiaaldemokraatlikeks paikadeks mängisid kõrtsmikud. Nimetatud perioodil oli kõrtsmikule saanud osaks teatavat laadi kontrollifunktsioon. Nimelt lubas kõrtsmik tagakambrisse astuda ainult spionaažis mittekahtlustatavatel külastajatel ning politseireidide korral oli tema ülesandeks sellest salaja koosolekut pidavale seltskonnale kellukesehelinaga märku anda. Kuid ka pärast 1890. aastat hoolitses kõrtsmik selle eest, et seltsimehed saaksid omaette olla, korraldades vastavalt ümber näiteks interjööri: riputades üles punased kardinad, laotades laiali sotsiaaldemokraatlikud päevalehed või pannes seintele üles sotsialistlike teerajajate ja riigipäevaliikmete portreed. Samaaegselt püüdis ka partei korraldada, et aatekaaslased ei külastaks teisi kõrtse. Korrapäraselt ilmusid partei vaadetega haakuvates või partei väljaantavates ajalehtedes nimekirjad lokaalidest, mille külastamisest soovitati hoiduda (vrd Berliini kohta Milhaud 1903: 76). Seda, et niisuguseid üleskutseid ka edu saatis, on võimalik Hamburgi puhul kinnitada. 
Kui 1890. aastate keskel arvestatav hulk varem sotsiaaldemokraatliku suunitlusega kõrtsmikke - lootuses paremal järjel ja maksejõulisemat klientuuri ligi meelitada - omakorda pead tõstvate juudivastaste poolele asus, boikoteerisid sotsiaaldemokraadid selliseid lokaale ja sundisid sel moel terve rea kõrtsmikke, kelle lootused polnud oodatud vilja kandnud ja kes olid sel moel hävingu äärele sattunud, sotsiaaldemokraatia juurde tagasi pöörduma (vt Evans 1989: 27 jj).

Oli ka kõrtsmikke, kellele linnavalitsus ja lõpuks ka sõjavägi sel määral survet avaldasid, et nad juba välisustele kinnitatud siltidega sotsiaaldemokraatidele mõista andsid, et nood pole antud asutuses oodatud. Teised kõrtsmikud kaunistasid ruume patriootlike piltidega ja saavutasid sel moel oma klientuuri homogeensuse. Kvantitatiivses plaanis saab sellise protsessi toimumist Hamburgi kõrtside puhul tõendada ainult tingimuslikult. Isegi nii hea vaatleja nagu kaitsepolitseinik Jochum on kõrtsikülastajate poliitilist meelsust maininud ainult 44,5 protsendis valikuliselt analüüsitud raportitest. Me ei tea, kas üksteisega kaarte mängivad ja mittepoliitilistel teemadel vestlevad külastajad alati just ühe ja sama partei ridadesse kuulusid. Kuid arvestades parteiüleste poliitikateemaliste vestluste vähesust - selgelt poliitilistest vestlustest moodustasid need ainult 5,4 protsenti - on alust siiski oletada, et külastajad jagasid üldjuhul sama poliitilist meelsust. ${ }^{12}$

Veelgi harvem tuli ette erinevate rahvuste esindajate vestlusi. Seda võib täheldada eriti saksa-poola kogukonna - ehk siis Hamburgi piirkonna suurima etnilise vähemuse - vaba aja veetmise mooduste puhul (vt selle kohta üldisemalt ka Hauschildt 1986). Raskem on järeldusi teha kristliku-judaistliku ja katoliku-protestantistliku taustaga külastajate suhete kohta. Arvestades Hamburgi elanike vähest kirikukuuluvust, oli inimeste usulisel taustal siin ebaoluline roll. Sellegipoolest ilmneb teiste vaba aja veetmise kohtade analüüsist, et segregatsioon toimus ka usulise kuuluvuse eraldusjoonte alusel (vt ka Blaschke 2002: 13-69). Oodatust vähem esineb aga soo alusel eristumist. Fakti, et käitumisõpikutes ikka ja jälle formuleeritud norm, mille järgi naised peaksid avalikke restorane külastama ainult oma abikaasa saatel ning kõrtse võimalusel üldse vältima (vt nt Eltz 1918: 472), tegelikkuses üldse paika ei pidanud, saab samuti tõendada valveraportite abil. Naised ei tõuse siin küll esile vestluspartneritena, kuid nad viibisid enamasti kohal, isegi kui nende osakaal oli keskmiselt ainult umbes 10 protsenti. $^{13}$

\section{Inimestevahelise kommunikatsiooni sisu}

Üldjuhul oli seega kõrtside puhul tegemist kinnise või poolavatud ruumitüübiga. Siiski näitab Hamburgi kõrtsimaastiku analüüs, et oli ka avalikke ruume: 
ruume, milles mõlema soo, erinevate rahvuste, parteide ja ühiskonnakihtide esindajad omavahel kokku puutusid. Kuidas kulges kommunikatsioon sellistel juhtudel? Millest räägiti ja millest ei räägitud? Järgnevas on eristatud kaks tüüpi vestlusi: mittepoliitilised ja poliitilised. Viimaste hulka kuuluvad mitte ainult vestlused, milles käsitleti poliitilise ja maailmavaatelise iseloomuga teemasid, vaid ka sellised, milles puudutati etnilist või soolist identiteeti. Seega võib isegi vestlus toiduvalmistamisest, kui selles tulevad esile teatud konnotatsioonid, liigituda päevapoliitiliseks vestluseks. Keskmes on muidugi sellised vestlused, milles käsitleti tõsiseid poliitilisi teemasid põhiseaduse-, sotsiaal-ja majanduspoliitika vallast.

Tööandjad olid Bismarcki perioodil ikka ja jälle esitanud soovitusi selliste teemade politiseerimisest kõrtsides loobuda (vt nt Krupp 1877, tsit Baedeker 1912: 160-168, siin 160 ja 165). Juba põgus pilk valveraportitele näitab aga, et just sotsiaaldemokraatlikud töölised ei teinud sellistest üleskutsetest mingit numbrit. Vaatamata kõigile 1914. aastani kestnud kontrollidele ja repressioonidele oli kõrts sotsialistide vastaste seaduste perioodil arenenud poliitilise arvamus- ja tegevusarenduse keskseks kohaks. Ka privaatsete kohtumiste käigus ei räägitud ainult ilmast ja mittepoliitilistest teemadest. Protokollides on dokumenteeritud, et välja ei jäetud ühtegi sise- ega välispoliitilist teemat. Eksistentsiaalse tähendusega küsimused, mis puudutasid näiteks töö- ja elamisolusid, on neis samavõrd kirja pandud nagu diskussioonid parteisiseste konfliktide, keisri käitumise või koloniaalpoliitika kohta. ${ }^{14}$

Sellegipoolest moodustavad poliitilised vestlused valveraportitest ainult väikese protsendi. Enamasti märgib ametnik, et "mingeid märkimisväärseid vestlusi" ei toimunud. See asjaolu ei ole tingitud ainuüksi arhiveerimisviisidest ${ }^{15}$ ega üleskirjutajate kirjutamistüdimusest. Isegi visad, poliitilistest sündmustest sügavalt huvitatud ametnikud kirjutavad üha külastajatest, kes pajatavad eranditult üksnes privaatsetest teemadest või ei vestle üldse, vaikivad, mängivad kaarte või piljardit. Jochumi ajavahemikus 7. detsembrist 1892 kuni 30. detsembrini 1893. kokku 375 kõrtsikülastust käsitleva 144 valveraporti valikuline analüüs näitab, et ta kohtas vaid 27,5 protsendil vaadeldud kõrtsidest külastajaid, kes rääkisid poliitilistest (valdavalt nende endi tööalast olukorda puudutavatest) küsimustest. Veel täiendava 5,3 protsendi puhul on konkreetsete andmete põhjal kõrtsikülastajate tavapärase koosnevuse kohta väga tõenäoline eeldada, et ka siin oli vestluste sisuks poliitika. Samas on rohkem kui kaks kolmandikku (67,2 protsenti) kõigist kirjapandud suhtlussituatsioonidest iseloomult mittepoliitilised. ${ }^{16}$

Kindlasti oleks aga ekslik teha nende arvude põhjal järeldusi kõrtsides liikuvate käsitööliste, kaupmeeste, õpetajate ja tööliste vähese politiseerumismäära kohta. Vastupidi: kui arvesse võtta asjaolu, et paljud inimesed rääkisid 
salakuulamist kartes ja hirmust häbimärgistamise ees üksteisega põhimõtteliselt vaikselt ning vahetasid uue, neile tundmatu külastaja lähenedes teemat või lõpetasid üldse vestluse, on põhjust oletada otseselt poliitiliste vestluste oluliselt suuremat hulka - protsenti, mis on vaba demokraatia alusel organiseerunud ühiskondade omast tõenäoliselt isegi suurem. Sellest annab tunnistust võrdlus ühe 1936. aastal Worktownis (pseudonüüm ühe Suurbritannia 180000 elanikuga linna kohta) läbiviidud andmekogumise tulemustega. Uurijaterühma Mass Observation andmetel käis 18 protsendis sealsetest vestlustest jutt pubidest ja joomisest, 16 protsendis kihlvedudest, 15 protsendis isiklikest asjadest, 13 protsendis spordist ja 6 protsendis ilmast. Kokku olid 68 protsendil kõikidest vestlustest sisuks mittepoliitilised teemad. Ainult 32 protsenti Workdowni vestlustest puudutasid valdkondi, mis olid laias laastus poliitilise iseloomuga: 12 protsendis tehti juttu elukutsest, 9 protsendis rahast, 8 protsendis päeva-poliitikast, 2 protsendis filmidest ja 1 protsendis sõjast (vt Mass Observation 1987 [1943]: 186j). 1960., 1970. ja 1980. aastatel Ameerika Ühendriikides ja LääneSaksamaal läbiviidud uuringud jõudsid sarnaste tulemusteni. Mitte kusagil ei kujutanud poliitika endast kõrtsivestlustes valdavat teemat (vt Clinard 1962: 280; Dunckelmann 1975: 248j; Miltner 1981: 161-196; Kraußlach \& Düwer \& Feeberg 1977: 147-153, 170-189; Kuhne \& Pistorius 1984: 361-368) ja peaaegu alati oli see "põimitud klientide elu-oluga seotud konteksti" (Wedemeyer 1990: 91). Ehk siis lühidalt kokku võttes: Saksa keisririigi alam- ja keskklass ei olnud kindlasti poliitikavabamad kui mitteautoritaarsete süsteemide kodanikud 20. sajandil.

\section{Inimestevahelise kommunikatsiooni vormid}

Igal juhul leidis poliitiline kommunikatsioon enamasti aset teatud miljöös. Üldjuhul oli tegemist konsensuslike aruteludega. Selles osalejad kuulusid samasse sotsiaalsesse keskkonda, nende vahel ei esinenud arvamuste lahknemist. Harva mainitakse esimese astme vaidlusi - vestlusi, milles osalejad on põhiküsimustes ühel nõul ja lahkarvamusi esineb vaid mingi ühe detaili osas. Veelgi harvem on dokumenteeritud teise astme vaidlusi, milles osalejad kuuluvad erinevatesse sotsiaalsetesse keskkondadesse ja sellele vastavalt jaotuvad nad mingi fundamentaalse eriarvamuse tõttu eri leeridesse, mis väljendub ka kirjeldatavas diskussioonis.

Kõigele eelöeldule vaatamata selliseid juhtumeid siiski oli. Järgnevas tehakse vahet nelja diskussioonitüübi vahel. Esiteks, dialoogiline vaidlus, mille käigus väljendatakse vastandlikke seisukohti verbaalselt ja mis lõpeb osapoolte ühele meelele jõudmisega. Ideaaljuhul päädib selline vestlus konsensusega vaba 
mõttevahetuse tulemusena; teine variant on, et konflikt peatatakse ja avaneb uus stseen, milles mõlemad vaidlejad pöörduvad üksmeelele jõudnuna kellegi kolmanda vastu (kes ei tarvitse üldse kohal olla). Tulemusetu vaidlus, mille käigus osapooled väljendavad oma üksteisele vastukäivaid arvamusi ilma üksmeelt saavutamata, kujutab endast dialoogilise vaidluse kolmandat varianti. Teiseks, monoloogiline vaidlus, mille puhul verbaalsele väljendamisele tuleb ainult üks seisukoht ning teistsugusel arvamusel olev vestluspartner on lihtsalt vaikivalt kohal - kui passiivne sõnatu kuulaja või aktiivne vestlusosaline, kes annab teisele osapoolele konfliktipelgliku vaikimise või mitteverbaalsete žestide või miimika kaudu märku, et ta sooviks teemavahetust. Kolmandaks, eskaleeruv vaidlus, mille käigus osapooled lähevad oma arvamuste erisuse tõttu sedavõrd tülli, et lõpetavad äkitselt vestluse ja vahel lahkuvad isegi ruumist. Neljandaks, vägivallaks üle minev vaidlus, mille puhul osapooled lasevad käiku kas otsese või kaudse vägivalla.

Kui valveraportites dokumenteeritud esimese või teise astme vaidlusi nende nelja diskussioonitüübi valguses vaadelda, ilmnevad sama sotsiaalse keskkonna ja erineva sotsiaalse keskkonna liikmete vahelistes juhtumites olulised erinevused. Samasse sotsiaalsesse keskkonda kuuluvate isikute diskussioonides domineerib üheselt dialoogiline vaidlus (93,3 protsendil). Sealjuures olid neis enamasti teemaks küsimused poliitilise strateegia ja taktika detailidest. Juhtumid, mil maailmavaatelised põhimõtteküsimused dialoogilisel viisil läbi arutati, olid palju harvemad: teise astme vaidlustest moodustasid need ainult 30 protsenti. Palju sagedamini esines vaidluste eskaleerumist, täpselt pooltel vaadeldud juhtudel katkestas üks osapool vestluse. Võrdluseks oli esimese astme vaidluste puhul selliseid juhtumeid ainult 6,7 protsenti. Monolooge ei esine siin üldse, seevastu teise astme vaidluste hulgas on neid siiski 20 protsenti. Vägivalda pole raportites dokumenteeritud - ei otsest ega kaudset. ${ }^{17}$ Ent selles aspektis ei ole valveraportid päris usaldusväärne allikas. Teistest allikatest ilmneb, et just rahvuslik-konservatiivsetes ringkondades olid riigivaenulike kõnede puhul otsesed sanktsioonid laialt levinud. Selle illustratsiooniks olgu toodud järgnev näide majesteedi solvamisest.

Polnud ühtegi teist isiksust, kes oleks olnud nii vastuoluline kui keiser Wilhelm II. Tema pooldajaid ja vastalisi leidus kõikides parteides, ühiskonnakihtides ja usuvooludes. Isegi sotsiaaldemokraatlike proletaarlaste hulgas ei olnud kõik keisri suhtes ühtviisi vaenulikult meelestatud (Cattaruzza 1991). Ühtlasi suhtusid mitmed katoliku taustaga piirkonnad keisrisse rahumeelselt. ${ }^{18}$ Alles Esimese maailmasõja ajal hakkas suurenev rahulolematus keisri autoriteeti vähendama (vt Ullrich 1997: 143-153). Kõigis ringkondades, ka evangeelse kodanikkonna seas oli kosta kriitilisi hääli, mis väljendasid eelkõige pahameelt Wilhelmi diplomaatilise saamatuse üle. Ilma kahtluseta olid 
sotsiaaldemokraatlik ja ka katoliiklik töölisliikumine keisri suhtes valdavalt siiski vaenulikult meelestatud (vt kirjeldusi Baieri töölisliikumise kohta Blessing 1979: 195-197). Seevastu rahvuslik-konservatiivne elanikkond suhtus keisrisse tugeva poolehoiuga. Sellele vastavalt olid pingelised ka viimatinimetatud rühma kuulujate vestlused Wilhemisse halvustavalt suhtuvate isikutega.

Rudolf Rocker, 1873. aastal Mainzis sündinud ning oma sotsiaaldemokraatlikelt vaadetelt anarhosündikalismi üle läinud sotsialismikriitik, on oma mälestustes ühte sellist olukorda kaasa elades kirjeldanud. Rocker, kes püüdis luua kontakti ühe 1848. aasta revolutsioonis osalenute grupiga, oli ükskord tunnistajaks, kuidas selle kaheksa- kuni kümnepealise mässuliste kamba juht ehk vana Volck ühe süütu märkuse pärast kolmeks kuuks vanglasse pisteti. Lihtsates oludes elav Volck istus koos sõbraga kõrtsilaua ääres, mille juures oli koha sisse võtnud ka üks Preisi veltveebel. Nende laua juurde tuli itaallasest kipskujukeste müüja, kes pakkus müüa keiser Wilhelm I kujukesi. Vana Volck saatis ta minema sõnadega: "Aitäh, aga mina olen vabariiklane ega oska selliste asjadega midagi pihta hakata." Kui selle peale sekkus veltveebel ja hakkas müüjaga tingima, olles nõus maksma talle ainult poole hinnast ehk 25 penni, torkas Volck vahele: “Ühele Preisi veltveeblile peaks see mehike küll veel vähemasti 50 senti väärt olema." Sellega oli ta endale liiga palju lubanud. Sõjaväelane lahkus kõrtsist ja saabus tagasi politseinikuga, kes vana revolutsionääri vahistas. Rockerile, kes oli enda arusaamist mööda tähenduslikele sõnadele vastuvõtlik, mõjus see vahejuhtum katalüseerivalt. Volcki arvamuses, et "ülalt tulevat vägivalda on võimalik kõrvaldada vaid altpoolt tuleva vägivallaga" oli Rockeri jaoks "midagi haaravat, mida Preisi politseimajanduse jõhker reaalsus veelgi süvendas". Noorsotsialist Rocker liitus parteiaktivistidega, kes vastandusid August Bebelile ja Friedrich Engelsile ning pidasid parlamentaarseid reforme illusoorseteks. 18aastaselt hakkas Rocker juba lähenema anarhismile (Rocker 1974: 18-20).

Säilinud mälestuste põhjal pole võimalik selliste kogemuste tegelikku hulka hoomata. Lugejat huvitavad konfliktid - konfliktivaesed vestlused tekitavad igavust. Sellevääriliselt konfliktitiined on ka memuaarides tunnistaja vaatevinklist kirjeldatud dialoogid. Kahtlemata on põhjust arvata, et tegelike kogemuste hulk ei avaldanud grupispetsiifiliste kujutelmade ja käitumisviiside kujunemise juures nii suurt mõju kui intensiivsus, millega oluliseks peetud sündmusi vahendati ja grupi kollektiivses mälus elavana säilitati. Pole juhuslik, et ka Rocker paigutas selle vahejuhtumi kirjelduse oma rohkem kui kolmesajaleheküljelise biograafia algusesse, kus see on osa rännakust, mis juhatab lugeja Mainzist läbi Prantsusmaa, Inglismaa ja Saksamaa Ameerika Ühendriikidesse, kus Rocker 1958. aastal suri. Vestlused nagu eelnimetatu ei apelleeri tingimata representatiivsusele, ent omaaegses teadvuses on neid siiski 
peetud representatiivseks. Tõepoolest: peaaegu kõigis läbivaadatud keisririigiaegsetes töölisliikumise liikmete omasõnalistes tunnistustes esineb juhtumeid, kui politsei või tööandjad on sellistesse vestlustesse jõuliselt sekkunud. Paljudel kirjeldatud juhtudel järgnes veel järelfaas: näiteks lasti asjassepuutuv isik töölt lahti, viidi kohtu ette või määrati talle majesteedi solvamise eest vanglakaristus.

On iseloomulik, et niisuguseid juhtumeid ei leidu asjakohastes kirjeldustes suhtlussituatsioonide kohta, milles osalesid ainult proletariaadi esindajad. Vähene sanktsioonivalmidus kerkib aeg-ajalt isegi vestlustes endis üles, näiteks vaidluses, mis tekkis 4. augustil 1893 ühes Hamburgi keldribaaris sotsiaaldemokraatliku pottsepa ning keisrile lojaalse raudteetöölise ja tolle sõbra vahel. Kolm joobnud olekus vestluspartnerit jõudsid oma vestluses jutuga keisrini. Kui pottsepp väljendas oma taunivat suhtumist ("Mina ei ehita keisrile mingeid ahje ega ka muud, kui ta ka seda paluma peaks"), alustas raudteetööline demonstratiivselt laulu "Ma olen preislane, kas tunnete mu värve?". Pottsepp hüüab selle peale otse: "Mis, sa oled preislane? [---] siis oled ju midagi parempoolset! Mina olen ehtne sotsiaaldemokraat." Seejärel ütleb tööline: “Jah, olen uhkusega preislane, Pommeris sündinud ja praegu olen kuninglik preisi riigiraudtee töötaja!" See vastus provotseerib sotsiaaldemokraatlikku pottseppa sedavõrd, et ta hakkab "Marseljeesi" viisil laulma laulu "Kuskil kaugel paksus metsas" ning lõpetab majesteedi solvamisega: "Kes see keiser õieti on? Minu silmis pole keiser üldse keegi! Kui tahad, mine anna mind üles!” Selleni aga ei lase tema keisrile lojaalsed vestluspartnerid end viia. Nad tõusevad püsti ja lahkuvad kõrtsist, kusjuures üks neist lausub: "Kui sa seda rumalat loba ei lõpeta, lähen minema, ma ei taha sellise jamaga mingit tegemist teha. Sa ei tea ise ka enam, mida räägid.” Kõrtsiproua pöördub neljanda külastaja ehk inkognito kohalviibiva kaitsepolitseiniku Hopstocki poole, püüdes olukorda järgmiste sõnadega siluda: "Kuidas võib end niimoodi unustada? Kui ta kaine on, on ta suurepärane inimene."19

Nii sageli kui töölisrahva seas ka Wilhelm II poliitilist tegevust ei arutatud ja nii vastandlikud kui need vestlused ka polnud, jõustruktuuride kaasamist allikates ei mainita - ei minavormis tunnistustes ega valveraportites, kuid enamasti kulgesid sellised vestlused siiski verbaalse eskaleerumise mustrit järgides. Iseloomulik on protsess, mis rullus lahti 27. mail 1893 kella 21 ja 22 vahel lokaalis J. Bohnsack ehk ühes Hamburgi kõrtsis, mida valdavalt külastasid sillutisepaigaldajad, sadamatöölised ja veevärgitöölised. Kaitsepolitseinik Hopstock oli tunnistajaks vaidlusele, mis leidis aset kuue ühe laua taga istuva töölise vahel. Parasjagu kritiseeris üks neist teraval toonil keisri pikki, palgatööliste kulul toimuvaid lõbureise ("Kes peab kõik need reisid kinni maksma? Töölised - meil vaestel inimestel tõmmatakse see vähenegi nahk üle kõrvade."). Sõbralikult, kuid otsustavalt vastandus talle lauanaaber: "Las 
ta olla, seni pole meil oma keisri üle põhjust küll kaevata, ta on juba väga palju head sisse viinud ja ta ei saa ka alati kõike nii teha, nagu tahab. [---] Ta on töölisklassi heaks juba rohkem teinud kui tema eelkäijad. Mina saan seda meest ainult kiita, seetõttu ei vali ma kunagi kandidaati, kes sotsiaaldemokraatide hulka kuulub." Kolmandale lauanaabrile, kes pooldas sotsiaaldemokraatiat, oli see juba liig. Vihaselt tõusis ta püsti ja lahkus seltskonnast sõnadega: "Kui sa seda tõesti usud, siis saa sellega õndsaks. Minu keiser on Bebel!” Ülejäänud kohalolijad ei näidanud üles ei pahameelt ega üllatust, vastupidi. "Niisuguste asjadega" ei tohi sellise inimese juures lagedale tulla, ta on "ehtne sotsiaaldemokraat", kommenteeris üks kohalejäänutest mõistvalt seda passiivse agressiooni akti. Antud reaktsioon viitab nimetatud kommunikatiivse käitumise normaalseks pidamisele: ühelt veendunud sotsiaaldemokraatia pooldajalt polnud tema kaasaegsed ilmselgelt midagi muud harjunud ootamagi. Tõepoolest, kommunikatsioon vasak- ja parempoolsete vahel lõppes enamasti vestluse äkilise katkestamisega. ${ }^{20}$

Parteiüleste kõrtsivestluste kulgu määravaks teguriks oli seega peamiselt vestluses osalejate sotsiaalne päritolu. Kui keskklassi puhul leidub ikka ja jälle tunnistusi kõrgemate jõustruktuuride kaasamisest, siis töölised paistavad olevat sellest sekkumisviisist hoidunud - osalt solidaarsusest, osalt põhimõttelisest usaldamatusest riiklike võimukandjate vastu.

\section{Kokkuvõte ja järeldused}

Mõneski suhtes on kõrtsides toimuva kommunikatiivse käitumise kohta saadud tulemused representatiivsed. Seda näitab võrdlus käitumisega teistes piirkondades, näiteks õhtuseltskondades või töökohal (vt Owzar 2006). Läbivalt ilmneb, et ka pärast 1890. aastat ei saa rääkida keisririigis valitseva õhkkonna erosioonist. Vaid harva tavatsesid oma sotsiaalse keskkonnaga seotud inimesed teistmoodi mõtlejatega või uskujatega kontakti luua. Sealjuures ei kulgenud piirid mitte ainult sotsiaalsete kihtide vahel, vaid võisid neid ka läbistada. Vastavalt sotsiaalsele olukorrale ja etnilisele päritolule, poliitilisele meelsusele, usulisele või soolisele kuuluvusele kujunesid üksteise suhtes suuresti autonoomselt toimivad kommunikatsioonirühmad, mille teed vaid vähestel juhtudel ristusid.

Kui kattumisi ka ette tuli, kaldusid suhtlejad tülitekitavaid teemasid vältima. Parteide ja sooülene kommunikatsioon allus ülimalt tugevatele piirangutele; vastandlike vaadete üle diskuteerimine ja identiteedipõhiste erinevuste tõstatamine olid taunitud ja ühtlasi harvaesinevad. Võrreldavalt harvad pole ainult poliitilistel ja religioossetel teemadel peetud vaidluste ülestähendused, vaid ka vestlused maailmavaateliste küsimuste, teaduse või seksuaalsuse üle. 
Kõigi nende teemadega seostuv tabu tuli ilmsiks ka juhtudel, kui üks vestluspartneritest selle vastu eksis. Sest enamasti suubusid sellised vestlused vaikusesse, eskaleerusid või katkestati mõni minut hiljem. Väljaarvatud juhtudel, kui mõni valdavalt keskklassi kuuluv vestluspartner mõne üldjuhul vasakpoolse töölise politseile üles andis, esines kaudse või koguni otsese vägivalla kasutamist ülimalt vähe. Seetõttu ei saa ei vägivalda, käskimist ega kuuletumist nimetada argimiljöö keskseteks kommunikatsioonstrateegiateks. Palju enam oli normiks mitterääkimine, vaikimine.

Sellise vestlusstrateegia oli enamik inimesi omandanud juba lapse- ja noorukieas: sõjaväes, koolis või vanematekodus. Nimelt ei räägitud nii keskklassi kui ka proletaarsetes perekondades poliitikast üldse. Selles osas erineb saksa vaidluskäitumine 19. sajandi Inglismaa keskklassi perekondade omast - nimelt oli viimatinimetatute hulgas poliitilised päevasündmused "pidevalt suure tähtsusega" (Budde 1994: 376).

Siiski oleks Saksamaal vaadeldud kommunikatiivse käitumise põhjal ekslik järeldada, justkui oleks see poliitikakauge või alandliku loomuse väljendus, nagu seda 1980. aastate poliitilises kultuuriuurimises ikka ja jälle väideti (vt nt Greiffenhagen 1984: 54). Sest vaieldamatult olid enamikul nii ülem- kui alamja keskklassi kuuluvatest inimestest olemas kindlad poliitilised vaated ja nad ka väljendasid neid, kuid ilmselgelt ainult siis, kui olid omakeskis ega pidanud kartma mingeid vastuolusid või konflikte. Mitte poliitikakaugus, mitte alandlik loomus, vaid konfliktipelgus on seega valitsev käitumismuster, mille kohta on võimalik leida kinnitust peaaegu kõigist Saksa ühiskonnakihtidest.

Selle mustri põhjused on mitmetahulised, kindlasti ka antropoloogilist laadi. Suurt hulka inimkonnast - seda kinnitavad 1950. ja 1960. aastate sotsiaalpsühholoogilised uuringud - ajendab mittekuulumise hirm (vt Asch 1963; Milgram 1961) liituma enamuse hinnangutega isegi juhul, kui nad mõnes muus olukorras sellest kindlalt hoiduksid. On ka selliseid - nende kohta kasutab Elisabeth Noelle-Neumann (2001) väljendit "vaikimise spiraal" -, kes vaikivad isolatsioonihirmust. Siiski on antud juhul tegemist - ja ka seda kinnitavad uuringud ajaloo vältel muutuva fenomeniga. Selle massilise esinemise kohta keisririigis peab seega leiduma veel teisi seletusi. Keskset rolli mängisid absolutistliku autoritaarriigiga seotud tegurid. Paljud inimesed juhindusid (täiesti põhjendatult) hirmust töölt lahtilaskmise või karjääri rikkumise, pealtkuulamise või sanktsioonide ees. Mitte ainult kõrtsis, vaid ka töökohal (Loreck 1978: 178) ja õhtuseltskonnas, koolis või sõjaväes ei olnud vabalt rääkimine teretulnud, eriti juhtudel, kui inimene kuulus mõne ühiskondliku või poliitilise vähemuse hulka. Ainult omakeskis, mõttekaaslaste seltskonnas tohtis oma mõtteid avaldada, ning siis praktiseeriti solidaarsust ja ehitati üles oma eneseteadvust. 
Iseloomuliku kommunikatsioonikäitumise põhjusena ei tohiks alahinnata ka parteidest ja seltsidest lähtuvaid impulsse. Vaikimine oli kommunikatiivne praktika, mille sisseharjutamine toimus igal seltsi koosviibimisel ja parteikoosolekul. Ainult isik, kes allus täpselt paikapandud reglemendile, tohtis kaasa rääkida. Eriti just töölisliikumisel oli sellise distsiplineerimisvormi juures oluline roll. See ei kohandanud oma liikmeid mitte ainult vägivallast hoidumisele poliitiliste lahkarvamuste korral (vrd Welskopp 2000: 291-338), vaid distsiplineeris neid samamoodi toimima ka parteisisese konflikti korral, suunates näiteks dissidente vaikima.

Määrav oli veel üks põhjus: suurema osa kodanike kartus paisata segi vaevaga saavutatud tasakaal ühiskondlike kihtide ja konfessioonide, parteide ja rahvuste vahel. Tavatult tugevalt formeerunud konfliktialgete ja väheste atraktiivsete konsensusevalikute tõttu kartsid paljud vestlustes osalejad, et erimeelsused võiksid vallandada tõsisema põhimõtete kokkupõrke. Selles mõttes oli vaikimine üpris toimiv konfliktivältimise moodus. Selle omaaegse kommunikatiivse käitumise edukuse hindamine Habermasi diskursuse-ideaali põhjal ei tundu kõnesolevas ajaloolises situatsioonis asjakohane (vrd Habermas 1984: 174-183), sest võttes arvesse latentseid pingeid, oli toona iseenesest mõttekas teiste usuvoolude või poliitiliste ideede esindajatele mitte ette jääda, potentsiaalseid tülivallandajaid vältida või eskaleeruv vestlus otsustavalt lõpetada.

Nii toimiv, kui see strateegia ka kuni 1914. aastani polnud, tõi see pärast Esimest maailmasõda, kui Saksa ühiskond oma labiilsest tasakaalust välja vajus, kaasa ka negatiivseid tagajärgi. Katoliiklike ja sotsiaaldemokraatlike ühiskonnasegmentide olemasolu küll stabiliseeris poliitilist süsteemi (vt Walter \& Matthiesen 1997: 55), kuid teisalt röövis konfliktilahendusstrateegiate puudumine ühiskonna demokraatlikult keskmelt võimaluse nii parempoolsel kui vasakpoolsel ühiskonnatiival radikaliseeruvaid elemente taasintegreerida. Siin tuleb näha olulist erinevust rääkimise ja tülitsemisega harjunud poliitikute ja ühiskondliku üldsuse vahel. Kui poliitikud oskasid - välja arvatud natsionaalsotsialistide puhul - kommunikatiivse tingimise ja kompromissisaavutamise strateegiat ka argipäevas edukalt kasutada (vt Mergel 2002), siis laiem üldsus tõmbus valdavalt poliitilistest tülidest tagasi ja loobus eriarvamuste produktiivsest läbitöötamisest. Sellega polnud neil aga äärmuslaste kasutatavale vägivallale omalt poolt midagi vastu panna ning neil puudus suutlikkus välja pakkuda mõnda ühiskondlikku kihistumist ületavat demokraatlikku platvormi. Veelgi fataalsem oli tõenäoliselt mitterääkimises manifesteeruv empaatiapuudus eskaleeruva terrori ohvrirühmade suhtes. Protestikäitumist esines harva, peaaegu alati domineeris vaikimine, kuid eks on seegi üks tegutsemise vorme.

Tõlkinud Reet Hiiemäe 
Originaal: Owzar, Armin (2004). Konfliktscheu und beredtes Schweigen: Die Kneipe als Kommunikationsraum im deutschen Kaiserreich. Moving the Social-Journal of Social History and the History of Social Movements (Forschungen und Forschungsberichte), vol 31. Klartext Verlag, lk 43-58 (doi: 10.13154/mts.31.2004.43-58). ( Klartext Verlag Essen.

\section{Kommentaarid}

1 Vt selle kohta kirjutisi alates 1902. aastast seltsi Deutscher Arbeiter-Abstinentenbund väljaandes Der Abstinente Arbeiter.

${ }^{2}$ Kogu riigis oli 1895. aasta juuni seisuga keskmiselt üks kõrts iga 221 elaniku kohta (vt Schufftan 1903: 35).

3 Vt selle kohta eelkõige Wyrwa 1990: 157 j.

${ }^{4}$ Seetõttu aitab käesolev uurimus vastata ka küsimustele, mis seostuvad sotsiaalse miljöö, sooküsimuse ajaloo ja poliitilise kultuuri ajaloo uurimisega. Metoodiliste eelduste käsitlust ja arutelu nende teemade uurimise hetkeseisu kohta vt Owzar 2006.

5 Vthaakuvaid uurimusi Evans 1996; samuti artikleid kogumikus Herzig \& Langewiesche \& Sywottek 1983. Hamburgi linnaajaloo kohta hilisemas keisririigis vt Jochmann 1986.

6 Järgnevas tsiteeritud viitega StaatsA HH, 331-3, Politische Polizei, S 3930. Tegemist on kokku 50 üksusega, millest mõned hõlmavad mitu (kuni 12) köidet. Valik nendest teadetest on ära toodud Evans 1989; Galerie Morgenland 1995. Allikakriitikat vt Evans 1989: 7-39.

7 Hamburgi kohta vt ka Nahrstedt 1970.

8 Täpseid andmeid elanikkonna sotsiaalse ja usulise kuuluvuse kohta vt Statistisches Bureau der Steuer-Deputation (Hg.). Statistisches Handbuch für den Hamburgischen Staat 4, Hamburg 1891.

9 Analüüsiti 144 valveraportit, mille oli koostanud kaitsepolitseinik Jochum - üks eriti häid kõrtsiklientuuri sotsiaalse koosnevuse vaatlejaid - ajavahemikul 7. detsembrist 1892 kuni 30. detsembrini 1893 (StaatsA HH, 331-3, Politische Polizei, lk 390-394, Bd. 1).

${ }^{10}$ See tõik ilmneb ka sama ajastu mälestustest, nt Alfred Lichtwarki raamatust "Hamburg. Niedersachsen" (Lichtwark 1897).

${ }^{11}$ Selleks analüüsiti 184 valveraportit, mille koostasid kaitsepolitseinikud Jochum, Meyer ja Scharnweber, kes olid eriti head kõrtsiklientuuri elukutsepõhise koosnevuse vaatlejad, ajavahemikes 7. detsembrist 1892 kuni 30. detsembrini 1893 (Jochum), 24. maist kuni 19. augustini 1910 ja 17. oktoobrist kuni 31. detsembrini 1910 (Meyer) ning 17.juunist kuni 3. augustini 1910 ja 22. oktoobrist kuni 18. novembrini 1910 (Scharnweber) (StaatsA HH, 331-3, Politische Polizei, lk 3930-3934, Bd. 1 S 3930-48 ja S 3930-50).

12 See tulemus on saadud 92 kõrtsivestluse põhjal, mis olid ära toodud 135 valveraportis, mille koostas kaitsepolitseinik Jochum ajavahemikus 7. detsembrist 1892 kuni 30. detsembrini 1893 (StaatsA HH, 331-3, Politische Polizei, S 3930-4, Bd. 1).

${ }^{13}$ Selle leiu aluseks on kaitsepolitseinik Meyeri poolt 1910. aasta mais ja juunis koostatud valveraportite analüüs (StaatsA HH, 331-3, Politische Polizei, lk 3930-3948).

${ }^{14}$ See asjaolu ilmneb juba Evansi väljaantud kõrtsivestluste sisukorrast (Evans 1989). 
${ }^{15}$ Nende dokumentide puhul, mis olid korpusest eraldatud ja liidetud muude aktide juurde, leidub neid ainult murdosa jagu, ja see ei moonuta üldpilti.

${ }^{16}$ Vaadeldi kaitsepolitseinik Jochumi 7. detsembrist 1892 kuni 30. detsembrini 1893 kirjapandud 144 valveraportit, mis dokumenteerivad kokku 375 kõrtsikülastust (StaatsA HH, 331-3, Politische Polizei, S 3930-4, Bd. 1).

${ }^{17}$ Vaadeldi kokku 25 vaidlust, mille olid oma valveraportites ära toonud kaitsepolitseinikud Fritze, Jochum, Sokolowski, Hopstock, Erxleben, Graumann, Kramer, Noroschat, Zerulli ja Szymanski (StaatsA HH, 331-3, Politische Polizei, S. 3930-3, Bd. 2; S 3930-4, Bd. 1,2 u. 3; S. 3930-9; S 3930-10; S 3930-21, Bd. 4-5; S 3930-22, Bd. 2,3,5-8; S 393028, Bd. 2; S 3930-30, Bd. I; S 3930-38, Bd. 2 und S 3930-40, Bd. 2 u. 3).

18 Sellest annavad muuhulgas tunnistust keisri sünnipäeva auks peetud avalikud pidustused, mis viitavad masside poolehoiule isegi riigi nii sügavalt paavstitruudes piirkondades ja linnades nagu Münster (vt Weiß 1993: 118j).

19 Kaitsepolitseinik Hopstocki valveraport 4. augustist 1893 (StaatsA HH, 331-3, Politische Polizei, S 3930-10, ilmunud ka Evans 1989: 328j).

${ }^{20}$ Hopstocki valveraport 27. maist 1893 (StaatsA HH, 331-3, Politische Polizei, S 393010, ilmunud ka Evans 1898: 328).

\section{Allikad}

StaatsA HH = Staatsarchiv Hansestadt Hamburg

\section{Kirjandus}

Asch, Solomon E. 1963. Effects of Group Pressure upon the Modification and Distortion of Judgments. Guetzkow, Harold (toim). Groups, Leadership and Men. Research in Human Relations. Reports on Research Sponsored by the Human Relations and Morale Branch of the Office of Naval Research 1945-1950. New York, lk 177-190.

Baedeker, Diedrich 1912. Alfred Krupp und die Entwicklung der Gußstahlfabrik zu Essen. Mit einer Beschreibung der heutigen Kruppschen Werke. Nach zuverlässigen Quellen. Essen: G. D. Baedeker, lk 160-168.

Berding, Helmut 1988. Moderner Antisemitismus in Deutschland. Frankfurt am Main: Suhrkamp.

Blaschke, Olaf 2002: Der "Dämon des Konfessionalismus". Einführende Überlegungen. Blaschke, Olaf (toim). Konfessionen im Konflikt. Deutschland zwischen 1800 und 1970: ein zweites konfessionelles Zeitalter. Göttingen: Vandenhoek \& Ruprecht, lk 13-69.

Blessing, Werner K. 1979. Der monarchische Kult, politische Loyalität und die Arbeiterbewegung im deutschen Kaiserreich. Ritter, Gerhard A. (toim). Arbeiterkultur. [täiendatud väljaanne brošüürist Worker's Culture des JCH 13/2 (April 1978)]. Königstein: i.Ts., Athenäum Verlag et al., lk 185-228.

Budde, Gunilla Friederike 1994. Auf dem Weg ins Bürgerleben. Kindheit und Erziehung in deutschen und englischen Bürgerfamilien 1840-1914. Göttingen: Vandenhoeck \& Ruprecht. 
Cattaruzza, Marina 1991. Das Kaiserbild in der Arbeiterschaft am Beispiel der Werftarbeiter in Hamburg und Stettin. Röhl, John C. G. \& Müller-Luckner, Elisabeth (toim). Der Ort Kaiser Wilhelms II. in der deutschen Geschichte. München: Oldenbourg Wissenschaftsverlag, lk 131-144 (https://www.academia.edu/37298985/Das_Kaiserbild_ in_der_Arbeiterschaft_am_Beispiel_der_Werftarbeiter_in_Hamburg_und_Stettin 7. mai 2020).

Clinard, Marshall B. 1962. The Public Drinking House and Society. Pittman, David J. \& Snyder, Charles R. (toim). Society, Culture, and Drinking Patterns. New York \& London: John Wiley \& Sons, lk 270-292.

Dunckelmann, Henning 1975. Lokale Öffentlichkeit. Eine gemeindesoziologische Untersuchung. Stuttgart \& West-Berlin \& Köln \& Mainz: Kohlhammer.

Eltz, J [an] v[an der] [aka Tony Kellen] 1918. Das goldene Anstandsbuch. Ein Wegweiser für die gute Lebensart zu Hause, in Gesellschaft und im öffentlichen Leben. Essen: Fredebeul \& Koenen.

Evans, Richard J. (toim) 1989. Kneipengespräche im Kaiserreich. Die Stimmungsberichte der Hamburger Politischen Polizei 1892-1914. Reinbek: Rowohlt.

Evans, Richard J. 1996. Tod in Hamburg. Stadt, Gesellschaft und Politik in den CholeraJahren 1830-1910. Reinbek: Rowohlt.

Galerie Morgenland (toim) 1995. "Ich erlauschte folgendes Gespräch:...”. Mit Polizeispitzeln durch Eimsbütteler Kneipen der Jahrhundertwende. Hamburg: Galerie Morgenland.

Greiffenhagen, Martin 1984. Vom Obrigkeitsstaat zur Demokratie. Die politische Kultur in der Bundesrepublik Deutschland. Reichel, Peter (toim). Politische Kultur in Westeuropa. Bürger und Staaten in der Europäischen Gemeinschaft. Bonn: Bundeszentrale für Politische Bildung, lk 52-76.

Habermas, Jürgen 1984. Wahrheitstheorien. Habermas, Jürgen. Vorstudien und Ergänzungen zur Theorie des kommunikativen Handelns. Frankfurt am Main: Suhrkamp, lk 127-183.

Haupt, Heinz-Gerhard (toim) 1994. Orte des Alltags. Miniaturen aus der europäischen Kulturgeschichte. München: C. H. Beck.

Hauschildt, Elke 1986. Polnische Arbeitsmigranten in Wilhelmsburg bei Hamburg während des Kaiserreichs und der Weimarer Republik. Dortmund: Forschungsstelle Ostmitteleuropa.

Herzig, Arno \& Langewiesche, Dieter \& Sywottek, Arnold (toim) 1983. Arbeiter in Hamburg. Unterschichten, Arbeiter und Arbeiterbewegung seit dem 18. Jahrhundert. Hamburg: Verlag Erziehung und Wissenschaft.

Jochmann, Werner 1986. Handelsmetropole des Deutschen Reiches. Jochmann, Werner \& Loose, Hans-Dieter (toim). Hamburg. Geschichte der Stadt und ihrer Bewohner 2: Vom Kaiserreich bis zur Gegenwart. Hamburg: Hoffmann und Campe, lk 15-129.

Kautsky, Karl 1890/91. Der Alkoholismus und seine Bekämpfung. Die Neue Zeit 9/2 (1890/91), lk 1-8, 46-55, 77-89, 105-116.

Kraußlach, Jörg \& Düwer, Friedrich W. \& Feberg, Gerda 1977. Aggressive Jugendliche. Jugendarbeit zwischen Kneipe und Knast. München: Juventa. 
Krupp, Alfred 1877. Ein Wort an die Angehörigen meiner gewerblichen Anlagen. Essen, 15. März 1877.

Kuhne, Diethard \& Pistorius, Lea 1984. Über die psychosoziale Funktion der Kneipentheke für Angehörige der Kleinstadt-“Scene”. Gruppendynamik. Zeitschrift für angewandte Sozialpsychologie 15 (4), lk 361-368.

Levenstein, Adolf 1912. Die Arbeiterfrage. Mit besonderer Berücksichtigung der sozialpsychologischen Seite des modernen Großbetriebes und der psycho-physischen Einwirkungen auf die Arbeiter. München: E. Reinhardt.

Lichtwark, Alfred 1897. Hamburg. Niedersachsen. Dresden: Gerhard Kühtmann.

Loreck, Jochen 1978. Wie man früher Sozialdemokrat wurde. Das Kommunikationsverhalten in der deutschen Arbeiterbewegung und die Konzeption der sozialistischen Parteipublizistik durch August Bebel. Bonn \& Bad Godesberg: Neue Gesellschaft.

Machtan, Lothar 1983. Streiks im frühen deutschen Kaiserreich. Frankfurt am Main \& New York: Campus Verlag.

Mania, Thomas 1997. “Weißte was - 'nen Schnaps?” Die Gaststätte als Kommunikationszentrum. Theorie und Praxis am Beispiel eines Dortmunder Wohnquartiers. Münster \& New York \& München \& Berlin: Waxmann.

Mass Observation 1987 [1943] = Mass Observation. The Pub and the People. A Worktown Study. London \& Melbourne \& Sidney \& Auckland \& Johannesburg.

Mergel, Thomas 2002. Parlamentarische Kultur in der Weimarer Republik. Politische Kommunikation, symbolische Politik und Öffentlichkeit im Reichstag. Düsseldorf: Droste.

Milhaud, Edgard 1903. La Démocratie Socialiste Allemande. Paris: F. Alcan.

Milgram, Stanley 1961. Nationality and Conformity. Scientific American 205, lk 45-51 (doi: 10.1038/scientificamerican1261-45).

Miltner, Wolfgang 1981. Kneipenleben und Street Work. Eine Analyse der Interaktionsund Kommunikationsstrukturen zweier Stammbesuchergruppen einer proletarischen EckKneipe und der in diesem Kontext möglichen Ansätze von Street Work. Tübingen: D. Gräbner.

Nahrstedt, Wolfgang 1970. Die Entstehung der Freizeit. Dargestellt am Beispiel Hamburgs. Ein Beitrag zur Strukturgeschichte und zur strukturgeschichtlichen Grundlegung der Freizeitpädagogik, Göttingen: Vandenhoeck \& Ruprecht.

Nipperdey, Thomas 1990. Deutsche Geschichte 1866-1918. 1. Arbeitswelt und Bürgergeist. München: C.H.Beck.

Noelle-Neumann, Elisabeth 2001. Die Schweigespirale. Öffentliche Meinung - unsere soziale Haut. München: Langen Müller.

Owzar, Armin 2006. "Reden ist Silber, Schweigen ist Gold". Konfliktmanagement im Alltag des wilhelminischen Obrigkeitsstaates. Konstanz: UVK Verlag.

Planert, Ute 1998. Antifeminismus im Kaiserreich. Diskurs, soziale Formation und politische Mentalität. Göttingen: Vandenhoeck \& Ruprecht.

Ritter, Gerhard A. \& Tenfelde, Klaus 1992. Arbeiter im Deutschen Kaiserreich 1871 bis 1914. Bonn: J. H. W. Dietz. 
Roberts, James S. 1980. Wirtshaus und Politik in der deutschen Arbeiterbewegung. Huck, Gerhard (toim). Sozialgeschichte der Freizeit. Wuppertal: Peter Hammer Verlag, lk 123-139.

Rocker, Rudolf 1974. Aus den Memoiren eines deutschen Anarchisten. Frankfurt am Main: Suhrkamp.

Schufftan, Georg 1903. Studien über die gewerbliche Entwickelung des Gast- und Schankwirtswesens in Deutschland. Breslau: Schatzky.

Schult, Johannes 1954. Die Hamburger Arbeiterbewegung als Kulturfaktor. Ein Beitrag zur hamburgischen Kulturgeschichte. Hamburg: K. Weltzien.

Statistisches Bureau der Steuer-Deputation (toim) 1891. Statistisches Handbuch für den Hamburgischen Staat 4. Hamburg.

Ullmann, Hans-Peter 1999. Politik im deutschen Kaiserreich 1871-1918. München: Oldenbourg.

Ullrich, Volker 1997. Die nervöse Großmacht. Aufstieg und Untergang des deutschen Kaiserreichs 1871-1918. Frankfurt am Main: S. Fischer.

Walter, Franz \& Matthiesen, Helge 1997. Milieus in der modernen deutschen Gesellschaftsgeschichte. Ergebnisse und Perspektiven der Forschung. SchmiechenAckermann, Detlef (toim). Anpassung, Verweigerung, Widerstand. Soziale Milieus, Politische Kultur und der Widerstand gegen den Nationalsozialismus in Deutschland im regionalen Vergleich. Berlin: Hentrich, lk 46-75.

Watzlawick, Paul \& Beavin, Janet H. \& Jackson, Don D. 1990. Menschliche Kommunikation. Formen, Störungen, Paradoxien. Bern \& Stuttgart \& Wien: Huber.

Wedemeyer, Georg 1990. Kneipe \& politische Kultur. Pfaffenweiler: CentaurusVerlagsgesellschaft.

Weiß, Gisela 1993. Kaiserfeiern in Westfalen - Zur politischen Kultur des Zweiten deurschen Kaiserreiches. Westfalen 71, lk 93-120.

Welskopp, Thomas 2000. Das Banner der Brüderlichkeit. Die deutsche Sozialdemokratie vom Vormärz bis zum Sozialistengesetz. Bonn: Dietz.

Wyrwa, Ulrich 1990. Branntewein und "echtes" Bier. Die Trinkkultur der Hamburger Arbeiter im 19. Jahrhundert. Hamburg: Junius.

Wischermann, Clemens 1983. Wohnen in Hamburg vor dem Ersten Weltkrieg. Münster: Coppenrath.

\title{
Summary
}

\section{Conflict-shy and eloquent silence:}

\section{Pub as a communication space in Imperial Germany}

\author{
Armin Owzar \\ Professor of history \\ Université Sorbonne Nouvelle Paris 3 \\ armin.owzar@sorbonne-nouvelle.fr
}


Keywords: communication, Imperial Germany, inns, social history, working class

The Wilhelmine society was hit by a huge number of social, political, religious, and ethnic conflicts. How did people deal with these conflicts in their everyday life? The article tries to answer this question by describing the different segments of an urban society (especially Hamburg) and their ways of face-to-face communication in pubs. A qualitative and a quantitative analysis of roughly 20,000 reports of investigation written by the Wilhelmine police, who over 22 years visited the pubs of Hamburg, shows that there was nearly no communication between the different segments of society. If they got into conversation, they normally did not talk about politics or anything else concerning their identity or beliefs. There are different reasons for this behaviour: anthropological reasons such as fear of isolation, and political reasons caused by the 'Obrigkeitsstaat'. One of the most important reasons is the variety of conflicts in Wilhelmine Germany itself. The social, religious, political, and ethnic problems were increasing alarmingly, so that silence seemed to be the most appropriate and reasonable strategy of managing conflicts.

For the development of Weimar society the results turn out to be ambivalent. On the one hand, this strategy of managing conflicts helped to stabilize the different 'milieus' and, as a result, the Weimar Republic. On the other hand, the same behaviour had serious consequences for the disintegration of German society and was responsible for lack of empathy shown towards the members of other 'milieus' and 'lager'.

Armin Owzar (snd 14. aprill 1964) on saksa ajaloolane ja alates 2013. aastast Pariisi 3. Ülikooli (Sorbonne Nouvelle) germanistika osakonna saksa ajaloo professor. Ta on avaldanud kolm monograafiat (Das preußische Berlin. Auf dem Weg zur europäischen Metropole, 1701-1914, 2019; "Reden ist Silber, Schweigen ist Gold”. Konfliktmanagement im Alltag des wilhelminischen Obrigkeitsstaates 2006; Sozialistische Bündnispolitik und gewerblich-industrieller Mittelstand. Thüringen 1945 bis 1953, 2001), olnud mitme artiklikogumiku toimetaja ja kirjutanud rea teadusartikleid sotsiaalajaloo teemadel.

Armin Owzar (b. 14 April 1964) is a German historian and history professor at the Department of German Studies of the New Sorbonne University Paris 3 since 2013. He has published three monographs (Das preußische Berlin. Auf dem Weg zur europäischen Metropole, 1701-1914 in 2019; "Reden ist Silber, Schweigen ist Gold”. Konfliktmanagement im Alltag des wilhelminischen Obrigkeitsstaates in 2006; and Sozialistische Bündnispolitik und gewerblichindustrieller Mittelstand. Thüringen 1945 bis 1953 in 2001), edited several collections of articles, and published a number of scientific articles on social, political and cultural history.

armin.owzar@sorbonne-nouvelle.fr 